\title{
Prey selection by two benthic fish species in a Mato Grosso stream, Rio de Janeiro, Brazil
}

\author{
Carla Ferreira Rezende ${ }^{1}$, Rosana Mazzoni ${ }^{2}$, Érica Pellegrini Caramaschi ${ }^{1}$, Daniela Rodrigues ${ }^{1}$ \\ \& Maíra Moraes ${ }^{2}$ \\ 1. Laboratório de Ecologia de Peixes, Instituto de Biologia, Departamento de Ecologia, Universidade Federal do Rio de \\ Janeiro, Av. Mal. Trompowski, s/n CCS Bloco AIlha do Fundão, 21941-590, Rio de Janeiro, RJ, Brazil; carlarezende. \\ ufc@gmail.com, erica.caramaschi@gmail.com, danitarodrigues@gmail.com \\ 2. Laboratório de Ecologia de Peixes, Instituto de Biologia Roberto Alcantara Gomes, Departamento de Ecologia, \\ Universidade do Estado do Rio de Janeiro, Rua São Francisco Xavier 524, 20550-900, Rio de Janeiro, Brazil; maz- \\ zoni@uerj.br, guiamaira@yahoo.com.br
}

Received 08-XI-2010. Corrected 10-III-2011. Accepted 07-IV-2011.

\begin{abstract}
Key to understand predator choice is the relationship between predator and prey abundance. There are few studies related to prey selection and availability. Such an approach is still current, because the ability to predict aspects of the diet in response to changes in prey availability is one of the major problems of trophic ecology. The general objective of this study was to evaluate prey selection by two species (Characidium cf. vidali and Pimelodella lateristriga) of the Mato Grosso stream, in Saquarema, Rio de Janeiro, Brazil. Benthos and fishes were collected in June, July and September of 2006 and January and February of 2007. Fish were collected with electric fishing techniques and benthos with a surber net. Densities of benthic organisms were expressed as the number of individuals per $/ \mathrm{m}^{2}$. After sampling, the invertebrates were fixed in $90 \%$ ethanol, and, in the laboratory, were identified to the lowest taxonomical level. Approximately, seventy individuals from each species were selected randomly in each month. Fishes were fixed in $10 \%$ formalin in the field and transferred to $70^{\circ} \mathrm{GL}$ ethanol in the laboratory. Fishes had their stomachs removed for subsequent analysis. Fish diet was described according to the numeric frequency method. The Manly Electivity Index was applied in order to verify prey selection. The most abundant families in both benthos and diet of both fish species were the same, indicating that these species consume mainly most abundant prey in the environment. We concluded that prey selection occurs even for preys that had small abundance in the environment. However, it is the availability of the macroinvertebrate resources that determines the major composition of items in diet of fish, demonstrating that the abundance is the factor that most influences the choice of prey. Rev. Biol. Trop. 59 (4): 1697-1706. Epub 2011 December 01.
\end{abstract}

Key words: electivity, trophic ecology, neotropical, stream fish.

The acquisition of food by fish is a process that usually involves search, detection, capture and ingestion (Keenleyside 1979, Dunbrack \& Dill 1983, Gerking 1994, Sih \& Christensen 2001, Warburton 2003), in which the time spent searching and the respective energy expenditure should be compensated by the energy contained in the prey (Dill 1983, Gerking 1994). The predator decision in select prey is related to abundance or size and is directly correlated to the amount of food in its stomach and its nutritional needs (Keenleyside 1979, Dill 1983).

One of the major limitations for fish during foraging is spatio-temporal environmental heterogeneity, and the appropriate predator decision will depend on the local situation. Nonetheless, some environmental characteristics are rhythmic and, thus, already internally predicted by the fish, but others are stochastic 
and unpredictable. Examples of these latter include local food availability, type of territory and risk of predation in a giving location (Dill 1983). Regarding stream-dwelling fish feeding behavior, it is assumed that many predators are generalist and feed upon organisms present in the water column, including those that fall from the riparian vegetation to the water surface, but others are specialized benthic predators (e.g. Aranha et al. 2000, Barreto \& Aranha 2006, Gomiero \& Braga 2008). However, these generalizations have been made based mainly on feeding studies in temperate areas, with species such as Salmo trutta (brown trout) and Oncorhynchus mykiss (rainbow trout) (Gregory et al. 2007). Nowadays there are some studies on the topic on tropical areas (e.g. Costa 1987, Esteves \& Lobón-Cerviá 2001, Barreto \& Aranha 2006, Mazzoni \& Costa 2007) that detected the same pattern.

Carnivorous guild is represented by a high number of fishes in most aquatic systems. One example is Salmo trutta that is a typical visual predator who select prey according to size and abundance in the environment (Rincón \& Lobón-Cerviá 1999). Morphological (Gatz 1979) and behavioral characteristics are the main constraints directly involved in the predator decision of prey species (Sazima 1986), reflecting the variability of feeding strategies used by fish (Keenleyside 1979). In any case, predators choose their prey in order to minimize energy expenditure in the search and capture of food and maximize the amount of energy available from prey consumption. Factors such as size, morphology and prey behavior influence this cost-benefit relationship (Stephens \& Krebs 1986).

Key to understand predator choice is the relationship between predator and prey abundance. Some models, based on fish from the temperate region, support the optimal foraging theory modeling the relationship between prey abundance and foraging time (Werner \& Hall 1974); others discuss additional factors acting in prey choice as size (Gill 2003). The basic predation model (Emlen 1966, MacArthur \&
Pianka 1966) shows that the predator focuses only on the most profitable prey and, when their abundance decreases, they feed without selectivity, using many different prey types (Gill 2003).

Many issues related to resource partitioning and habitat use by fish from neotropical streams are widely discussed (Sabino \& Castro 1990, Rezende et al. 2010) but there are few studies related to prey selection and availability (Rezende \& Mazzoni 2006, Pinto \& Uieda 2007, Carvalho 2008), while in the temperate region several studies, based on empirical data, have discussed prey selectivity (Mittelbach 1981, Cooper et al. 1985, Rincón \& Lobón-Cerviá 1999). According to Sih \& Christensen (2001), such an approach is still current, because the ability to predict aspects of the diet in response to changes in prey availability is one of the major problems of trophic ecology. The majority of studies on neotropical fishes describes some level of segregation across the aforementioned three major axes (Ross 1986): trophic (Esteves \& Lobón-Cerviá 2001, Deus \& Petrere 2003, Novakowski et al. 2008), spatial (Esteves \& Lobón-Cerviá 2001, Benneman et al. 2005) and temporal (Lobón-Cerviá \& Benneman 2000). It has also been shown that when the overlap along one axis is high, then segregation along the other axes is present (Lobón-Cerviá \& Benneman 2000, Esteves \& Lobón-Cerviá 2001, Benneman et al. 2005).

The optimal foraging theory started with models from Emlen (1966) and MacArthur \& Pianka (1966) and it was known as a theory with Schoener (1971). According to this theory we approached prey choice (Gill 2003) and hypothesize that fish predators choose prey regardless of their abundance. The objective of the present study was to evaluate the prey selection by two insectivorous stream benthic fishes (Rezende 2009, Mazzoni et al. 2010) Characidium cf. vidali Travassos 1967, family Crenuchidae and Pimelodella lateristriga (Lichtenstein 1823) family Heptapteridae from Mato Grosso stream. 


\section{MATERIALS AND METHODS}

Study site: The Serra do Mar, along the central and Southern Coast of Brazil, is formed by a complex net of streams rising up into its high altitudes, flowing through the Atlantic Rainforest, towards the Atlantic Ocean. The Atlantic Rainforest is the second largest tropical rainforest, after the Amazonian Hyalea. During recent decades, however, this vast region has been deforested and is nowadays reduced to $5 \%$ of its original distribution (Por 1992). However, the Atlantic Rainforest is considered one of the most important hotspots in the world regarding conservation priorities (Myers et al. 2000).

For the purpose of this study we selected the Mato Grosso stream, a typical Serra do Mar stream, located at the Eastern Coast of Brazil, distant approximately $70 \mathrm{~km}$ from Rio de Janeiro city (Serra do Mar, $22^{\circ} 55^{\prime} \mathrm{S}-42^{\circ} 35^{\prime} \mathrm{W}$ ). From its sources, at about $800 \mathrm{~m}$ above sea level, the stream drains a $30 \mathrm{~km}^{2}$ drainage area over the Northwestern areas of the Saquarema municipality (Rio de Janeiro) and leads into the Saquarema lagoon system. The $250 \mathrm{~m}$ long sampling section selected for this study is located at the uppermost reaches of the stream (22 $\left.53^{\prime} 13.7^{\prime \prime} \mathrm{S}-42^{\circ} 39^{\prime} 44.4^{\prime \prime} \mathrm{W}\right)$. This sampling section is characterized by abundant riparian vegetation and a substratum composed of rock, gravel, pebble and sand, along five succession of riffle, run and pool habitats. To prevent sampling-induced perturbations, the sampling section was divided into sub-sections as follows: the uppermost $50 \mathrm{~m}$ sub-section was used for benthic macro-invertebrates sampling and $50 \mathrm{~m}$ below that sub-section the fishes were collected at a $150 \mathrm{~m}$ long sub-section.

The Mato Grosso stream fish assemblage in the selected site was composed of five species, of which three, Astyanax taeniatus (Jenyns 1842), Characidium cf. vidali and Pimelodella lateristriga, were abundant and only a few, scattered individuals of Rhamdia quelen (Quoy \& Gaimard 1824) and Phalloceros harpagos Lucinda (2008) were recorded during the study period. We selected the two benthic most abundant species.

Voucher specimens were deposited at the Ichthyologic Collections of the Laboratório de Ictiologia da Universidade do Tocantins: Phalloceros harpagos (UNT 6771 to 6765) and the Museu Nacional do Rio de Janeiro: Astyanax taeniatus (MNRJ 29949 to 29954; 29962 to 29964; 29986 to $29988 ; 29990 ; 299994 ; 30000$; 30003; 30005; 30006; 30011; 30016; 30018; 30027), Characidium cf. vidali (MNRJ 29955, 29959, 29967, 29969 to 29971, 29989, 29992, 29997, 30004, 30007, 30009, 30012, 30015, 30017, 30021, 30024), Pimelodella lateristriga (MNRJ 29965, 29972, 29995, 30019, 30020, 30022), Rhamdia quelen (MNRJ 29991).

Sampling and data analysis: Benthos and fishes were collected in 10-11 of June, 15-16 of July and 20-21 of September of 2006 and 9-10 January and 13-14 February of 2007. Fish were collected with electric fishing techniques (Mazzoni et al. 2000, Rezende et al. 2010). Approximately 70 individuals were chosen randomly from each species were selected randomly in each month during all day (morning, afternoon and night), totalizing 323 specimens of Characidium cf. vidali and 358 Pimelodella lateristriga. Fishes were collected and sacrificed according to Brazilian environmental laws (Brazilian government permission IBAMA/MMA 02022.002475/2006-10, authorization number 118/2006-DIFAP/IBAMA). All individuals collected were analyzed. Benthos was collected with a surber net $(20 \times 20 \mathrm{~cm}$, mesh size of $250 \mu \mathrm{m}$ ) with a $250 \mu \mathrm{m}$ mesh screen sampling was conducted during the morning between 8-10a.m. On each sampling occasion, we collected 10 benthos samples for each type of substrate (rock, sand and leaf litter), totaling 150 samples at the end of the five sampling days. Densities of benthic organisms are expressed as the number of individuals per/ $\mathrm{m}^{2}$ (area of the Surber frame).

After sampling, the invertebrates were fixed in $90 \%$ ethanol and, in the laboratory, were identified to the lowest taxonomical level (Carvalho 1989, 1992, Carvalho et al. 2001, 
Olifiers et al. 2004, Salles et al. 2004, Borror \& Delong 2005, Pes et al. 2005, Passos et al. 2007 ) and counted. Fishes were fixed in $10 \%$ formalin in the field and transferred to $70^{\circ} \mathrm{GL}$ ethanol in the laboratory. Fishes had their stomachs removed for subsequent analysis and stomach items were identified and counted. Fish diet was described according to the numeric method (Hyslop 1980) that was expressed as frequencies and percentage frequencies.

The Manly's a Electivity Index (Manly et al. 1993) was applied in order to verify prey selection. This index was chosen because the prey consumed by the species was very low when compared to the environment prey (benthos).

$$
\alpha_{i}=\frac{r_{i}}{n_{i}}\left(\frac{1}{\sum\left(r_{j} / n_{j}\right)}\right)
$$

where:

$\alpha_{i}=$ Manly's $\alpha$ (preference index) for prey type $i$

$r_{i}, r_{j}=$ Proportion of prey $i$ or $j$ in the $\operatorname{diet}(i$ and $j=1,2,3 \ldots, \mathrm{m})$

$n i, n j=$ Proportion of prey type $i$ or $j$ in the environment

When selective feeding does not occur, $\alpha_{i}$ $=1 / m(m=$ number of prey types possible $)$.

If $\alpha_{i}$ is greater than $(1 / m)$, then prey species $i$ is preferred in the diet. Conversely, if $\alpha_{i}$ is less than $(1 / m)$, prey species $i$ is avoided (Krebs 1989). The preys that were on the environment and were not found on diet were considered avoided (Manly et al. 1993).

According to Lechowicz (1982), an electivity index is not robust when analyzing rare prey, because the low values compromise the analysis. Thus, we excluded preys items whose numeric proportions were less than $1 \%$ of the total proportion. This way, we analyzed the electivity data discarding the rare prey and the prey available in the environment but no verified in the diet. We considered that the latter were rejected by the fishes and they are not useful in the electivity analysis (Lechowicz 1982).

\section{RESULTS}

Benthic fauna: A total of 9825 individuals of 28 families were sampled in the benthos. Simuliidae, Chironomidae (families of Diptera) and Baetidae (family of Ephemeroptera) were the most abundant prey types (Table 1).

Diet composition: We collected 323 specimens of Characidium cf. vidali and 358 Pimelodella lateristriga were analyzed. Characidium cf. vidali consumed a total of 245 prey insects (total number of insects) and Pimelodella lateristriga consumed 276 preys items (total number of insects). Pimelodella lateristriga presented the most diverse prey consumption, totaling 33 different prey types while Characidium cf. vidali consumed 19 types of prey.

Prey more abundant in the diet of both species were Simuliidae (70.75\% and $30.81 \%$ ), Chironomidae $(7.78 \%$ and $13.58 \%)$ and Baetidae $(7.83 \%$ and $13.35 \%)$ The item Baetidae was the second more abundant in Characidium cf. vidali diet and Chironomidae was the second more abundant for Pimelodella lateristriga (Table 2).

Prey selection: According to $\alpha$ Manly's Preference Index Pimelodella lateristriga preferred Baetidae, Hydropsychidae and Leptoceridae while Characidium cf. vidali selected Simuliidae, Baetidae, Leptohyphidae and Leptophlebiidae. Despite being the second most abundant family in the benthos Simuliidae was not a preferred prey for both species. However Simuliidae was more abundant in the benthos and preferred only in the diet of Characidium cf. vidali (Table 3 ).

\section{DISCUSSION}

Characidium cf. vidali and Pimelodella lateristriga belong to the insectivorous guild (Rezende 2009, Mazzoni et al. 2010) that preyed mainly on benthic organisms. 
TABLE 1

Total density (ind $\mathrm{m}^{-2}$ ) and relative density (\%) of benthos organisms during the five sampling months (150 samples) in the Mato Grosso stream, Saquarema, Brazil

\begin{tabular}{|c|c|c|}
\hline & $\begin{array}{c}\text { Total } \\
\text { density }\end{array}$ & $\begin{array}{c}\text { Density } \\
(\%)\end{array}$ \\
\hline \multicolumn{3}{|l|}{ Ephemeroptera } \\
\hline Baetidae & 75.78 & 8.99 \\
\hline Leptohyphidae & 8.74 & 1.03 \\
\hline Leptophlebiidae & 21.78 & 2.58 \\
\hline \multicolumn{3}{|l|}{ Odonata } \\
\hline Anisoptera & 2.11 & 0.25 \\
\hline Zygoptera & 0.57 & 0.07 \\
\hline \multicolumn{3}{|l|}{ Plecoptera } \\
\hline Gripopterygidae & 3.38 & 0.40 \\
\hline Perlidae & 12.05 & 1.43 \\
\hline \multicolumn{3}{|l|}{ Trichoptera } \\
\hline Philopotamidae & 0.79 & 0.09 \\
\hline Leptoceridae & 14 & 1.66 \\
\hline Hydropsychidae & 12.38 & 1.46 \\
\hline Hydroptilidae & 3.44 & 0.40 \\
\hline Helicopsychidae & 0.56 & 0.06 \\
\hline Calamoceratidae & 0.85 & 0.10 \\
\hline Hydrobiosidae & 0.39 & 0.04 \\
\hline Glossosomatidae & 0.04 & 0.00 \\
\hline \multicolumn{3}{|l|}{ Lepidoptera } \\
\hline Pyralidae & 0.44 & 0.05 \\
\hline \multicolumn{3}{|l|}{ Coleoptera } \\
\hline Elmidae larvae & 50.26 & 5.96 \\
\hline Elmidae adult & 27.11 & 3.22 \\
\hline \multicolumn{3}{|l|}{ Diptera } \\
\hline Ceratopogonidae & 1.14 & 0.14 \\
\hline Chironomidae & 194.76 & 23.10 \\
\hline Simuliidae & 406.93 & 48.27 \\
\hline Empididae & 2.05 & 0.24 \\
\hline Tipulidae & 0.42 & 0.05 \\
\hline Dixidae & 0.17 & 0.02 \\
\hline Psychodidae & 0.04 & 0.01 \\
\hline \multicolumn{3}{|l|}{ Hemiptera } \\
\hline Veliidae & 0.22 & 0.03 \\
\hline \multicolumn{3}{|l|}{ Decapoda } \\
\hline Palaemonidae (Macrobrachium spp.) & 1.62 & 0.19 \\
\hline Trichodactylidae (Trichodactylus sp.) & 0.57 & 0.07 \\
\hline Total density of individuals (ind. $\mathrm{m}^{-2}$ ) & 843 & 100 \\
\hline Total number of individuals & 9825 & \\
\hline Total number of samples & 150 & \\
\hline
\end{tabular}

Considering Characidium cf. vidali diet, the prey with highest numeric frequency were Simuliidae, Baetidae and Chironomidae. These three families are described in the literature as benthic organisms associated mainly to rocky substrate or leaf litter (Merritt \& Cummins 1996). Species of the Characidium genus are benthic predators with sit-and-wait behavior (Sazima 1986, Sabino \& Castro 1990). Pimelodella lateristriga, is also classified as a benthic predator, foraging aquatic insects along the substrate (Casatti et al. 2001, Mazzoni et al. 2010), consuming the same preferential prey as Characidium cf. vidali. Pimelodella lateristriga also use diversified micro-habitats, but with the predominance of sandy substrate, and presents foraging habit of substrate speculation, with use of the sensory function of the cephalic barbels to capture prey. This behavior is common between heptapterid catfish as Imparfinis mirini, Phenacorhamdia tenebrosa, Pimelodella aff. gracilis (Casatti et al. 2001). Patterns of feeding activity and feeding tactics differed markedly among the two species. In Mato Grosso stream the two benthic species showed consistent diet patterns of feeding activity. Characidium fed more intensively during the day, Pimelodella exhibited the opposite pattern with maximum feeding intensity at night (Rezende 2009, Mazzoni et al. 2010).

The most abundant families in both benthos and fishes diet were the same, indicating that these species consume the most abundant prey in the environment. Relations are described in the literature, in which fish predators influence the densities of macroinvertebrates, which probably does not occur in the Mato Grosso stream, due to the dominance of Simuliidae, Chironomidae and Baetidae. In a review about experiments in streams, Wooster (1998) suggests that vertebrate predators have a moderate effect on prey density (invertebrates), while invertebrate predators have a stronger effect on the prey density (invertebrates). This occurs because vertebrate predators are able to forage a higher diversity of prey than invertebrate predators. 
TABLE 2

Numeric frequency and percentage numeric frequency of prey item consumed by Characidium cf. vidali (323 individuals) and Pimelodella lateristriga (358 individuals) during the five sampling months in the Mato Grosso stream, Saquarema, Brazil

\begin{tabular}{|c|c|c|c|c|}
\hline & \multicolumn{2}{|c|}{ Characidium $\mathrm{cf}$. vidali vidali } & \multicolumn{2}{|c|}{ Pimelodella lateristriga } \\
\hline & Total & $\%$ & Total & $\%$ \\
\hline \multicolumn{5}{|l|}{ Ephemeroptera } \\
\hline Baetidae & 5.83 & 7.83 & 6.61 & 13.35 \\
\hline Leptohyphidae & 2.11 & 2.83 & & \\
\hline Leptophlebiidae & 1.93 & 2.59 & 0.95 & 1.92 \\
\hline Ephemeroptera nymphae & & & 0.04 & 0.08 \\
\hline \multicolumn{5}{|l|}{ Odonata } \\
\hline Anisoptera & & & 0.58 & 1.17 \\
\hline Zygoptera & 0.02 & 0.03 & 0.04 & 0.08 \\
\hline Odonata unidentified & 0.33 & 0.44 & & \\
\hline \multicolumn{5}{|l|}{ Plecoptera } \\
\hline Gripopterygidae & 0.03 & 0.04 & 0.56 & 1.13 \\
\hline Perlidae & & & 0.41 & 0.83 \\
\hline \multicolumn{5}{|l|}{ Megaloptera } \\
\hline Corydalidae & & & 0.05 & 0.10 \\
\hline \multicolumn{5}{|l|}{ Trichoptera } \\
\hline Philopotamidae & 0.50 & 0.67 & 1.26 & 2.55 \\
\hline Leptoceridae & 0.47 & 0.63 & 2.96 & 5.98 \\
\hline Hydropsychidae & 0.43 & 0.58 & 1.52 & 3.07 \\
\hline Hydroptilidae & 0.89 & 1.20 & 0.98 & 1.98 \\
\hline Helicopsychidae & & & 0.56 & 1.13 \\
\hline \multicolumn{5}{|l|}{ Lepidoptera } \\
\hline Pyralidae & 1.44 & 1.93 & 1.56 & 3.15 \\
\hline \multicolumn{5}{|l|}{ Coleoptera } \\
\hline Elmidae larvae & 1.15 & 1.54 & 1.85 & 3.74 \\
\hline Elmidae adult & 0.47 & 0.63 & 0.55 & 1.11 \\
\hline Psephenidae & & & 0.05 & 0.10 \\
\hline \multicolumn{5}{|l|}{ Diptera } \\
\hline Ceratopogonidae & 0.01 & 0.01 & 0.10 & 0.20 \\
\hline Chironomidae & 5.79 & 7.78 & 6.72 & 13.58 \\
\hline Simuliidae & 52.68 & 70.75 & 15.25 & 30.81 \\
\hline Empididae & 0.32 & 0.43 & 3.14 & 6.34 \\
\hline Tipulidae & 0.01 & 0.01 & 0.26 & 0.53 \\
\hline Muscidae & & & 0.48 & 0.97 \\
\hline \multicolumn{5}{|l|}{ Terrestrial Insects } \\
\hline Lepidoptera & & & 0.03 & 0.06 \\
\hline Hymenoptera Formicidae & 0.05 & 0.07 & 0.75 & 1.52 \\
\hline Hemiptera & & & 0.25 & 0.51 \\
\hline Diptera & & & 0.02 & 0.04 \\
\hline Araneae & & & 0.04 & 0.08 \\
\hline Acari & & & 0.02 & 0.04 \\
\hline Blattodae & & & 0.02 & 0.04 \\
\hline \multicolumn{5}{|l|}{ Other items } \\
\hline Oligochaeta & & & 1.35 & 2.73 \\
\hline Osteichthyes & & & 0.02 & 0.04 \\
\hline Seed (vegetal matter) & & & 0.52 & 1.05 \\
\hline
\end{tabular}


TABLE 3

Manly's $\alpha$ electivity index calculated for prey with proportions higher than $1 \%$ in the diet of Characidium cf. vidali and Pimelodella lateristriga considering the five samplings of the Mato Grosso stream, Saquarema, Brazil

\begin{tabular}{lcc} 
& $\begin{array}{c}\text { Characidium } \mathrm{cf} . \\
\text { vidali }\end{array}$ & $\begin{array}{c}\text { Pimelodella } \\
\text { lateristriga }\end{array}$ \\
Baetidae & 0.11 & 0.13 \\
Leptohyphidae & 0.36 & \\
Leptophlebiidae & 0.13 & 0.07 \\
Perlidae & & 0.05 \\
Hydropsychidae & 0.05 & 0.19 \\
Leptoceridae & 0.05 & 0.34 \\
Elmidae adult & 0.02 & 0.03 \\
Elmidae larvae & 0.03 & 0.05 \\
Chironomidae & 0.04 & 0.05 \\
Simuliidae & 0.18 & 0.05 \\
\hline
\end{tabular}

Prey with $\alpha$ values $>0.1$ were considered preferred.

Other studies indicate that predators have little or no effect on benthic prey (Allan 1983). Cooper et al. (1990) argue that streams, due to the fact that they are closed systems, present very different results regarding predation, differing from terrestrial systems. One of the reasons is that some variables, such as current speed, act on organism distribution, affecting the relative importance of prey, in a way that other ecological relationships become more decisive regarding invertebrate densities, instead of predation by vertebrates (fish) (Cooper et al. 1990). The effects of fish foraging on invertebrates may also affect the densities, through indirect factors. Grazing and detritivorous fish have great impact on the communities of benthic invertebrates, through depletion or alteration of abiotic conditions (substrate scraping) (Flecker 1992, Gelwick et al. 1997). These indirect factors may be more important than the direct effects of predation (Flecker 1992).

In Mato Grosso stream Chironomidae was the second more abundant on benthos but was not a preferred prey for both species. Simuliidae was more abundant in the benthos and preferred only by Characidium cf. vidali. Pinto
\& Uieda (2007) studying a stream in the Atlantic Rainforest, observed that, in most cases of high selectivity by fish species, the insects presented a low frequency in the benthos. The low abundance of rare prey in the environment may affect the analysis of these indices, causing a false impression of a selected item (Lechowicz 1982, Manly et al. 1993). In the Mato Grosso stream, we decided to analyze the electivity data discarding the rare prey and the prey available in the environment but no verified in the diet. We considered that the latter were rejected by the fishes and they are not useful in the electivity analysis (Lechowicz 1982). These indices consider that food that occurs in higher proportions in the diet when compared to the environment is considered preferential, unlike the food that presents low occurrence in the diet and high occurrence in the environment (sensu Lechowicz 1982).

Pimelodella lateristriga selected Baetidae, Hydropsychidae and Leptoceridae contrasting with another study in Atlantic Rainforest stream where Pinto \& Uieda (2007) described that a heptapterid catfish preferred Lepidoptera and Diptera prey. Also this study Pinto \& Uieda (2007) described that Characidium zebra selected Plecoptera, differing from the Mato Grosso stream, where Characidium cf. vidali selected Diptera and Ephemeroptera. According to Carvalho (2008) plasticity in fish diet in Amazonian streams is related to the availability abundant prey. This author also argues that the ratio of high abundance of preys in the environment versus consumption of fishes represents a form of optimum foraging.

We conclude that in the Mato Grosso stream the fish species mainly consume the prey with the highest abundance in the environment. There is preference of non-abundant prey, demonstrating a feeding preference of the fish species for some food items. However, it is the availability of macroinvertebrate resources that determines the item composition in the diet of the two fish species, demonstrating that the factor influences the choice of prey the most is prey abundance. 


\section{ACKNOWLEDGMENTS}

This study is part of the Ph.D. Thesis of the senior author (CFR). The license for sampling was given by the Brazilian Institute of the Environment (Instituto Brasileiro de Meio Ambiente-IBAMA) (Process IBAMA/ MMA 02022.002475/2006-10, authorization number 118/2006-DIFAP/IBAMA). The study was supported by FAPERJ project $n$. E-26/170.578/2006 and by individual grants to CFR (CNPq 140928/2005-7; CAPES-PDEE 012008-01), EPC (CNPq 470587/2004-0) and RM (CNPq 311976/2004-0). Thanks are due to the staff of the Fish Ecology Laboratory (Laboratório de Ecologia de Peixes) UERJ and UFRJ for help in the field and laboratory and to Rachel Hauser Davis for the translation of the manuscript.

\section{RESUMEN}

Existen muy pocos estudios relacionados con la selección y disponibilidad de las presas por parte de sus depredadores. Actualmente, este enfoque se mantiene, debido a que uno de los principales problemas de la ecología trófica es la capacidad de predecir los aspectos de los hábitos alimentarios en respuesta a los cambios en la disponibilidad de las presas. El objetivo general de este estudio fue evaluar la seleccion de las presas en dos especies (Characidium cf. vidali y Pimelodella lateristriga) del arroyo Mato Grosso en Saquarema, Rio de Janeiro. Se recolectaron bentos y peces en junio, Julio y septiembre 2006 y en enero y febrero 2007. Los peces fueron recolectados con técnicas de pesca eléctrica y los del bentos con una red surber. La densidad de los organismos bentónicos se expresó como el número de individuos por $\mathrm{m}^{2}$. Luego del muestreo, los invertebrados se fijaron en $90 \%$ de etanol y se identificaron con el nivel taxonómico más bajo. Los peces fueron fijados con $10 \%$ de formalina en el campo y transferidos a etanol $70^{\circ} \mathrm{GL}$ en el laboratorio. Los estómagos de los peces fueron extirpados para su posterior análisis. Las familias más abundantes del bentos y las dietas de los peces fueron las mismas, lo que indica que estas especies consumen principalmente la presa más abundante en el ambiente. Se concluye que la selección de la presa se produce incluso para aquellas presas con una abundancia pequeña en el entorno. Sin embargo, es la disponibilidad de los recursos de los macroinvertebrados la que determina la mayor composición en términos de la dieta de los peces, demostrando que la abundancia es el factor que se ve más influenciado por la elección de presas.

\section{REFERENCES}

Allan, J.D. 1983. Predator-prey relationships in streams, p. 191-229. In J.R. Barnes \& G.W. Minshall (eds.). Stream ecology: application and testing of general ecological theory. Plenum, New York, USA.

Aranha, J.M.R., J.H.C. Gomes \& F.N.O. Fogaça. 2000. Feeding of two sympatric species of Characidium, $C$. lanei and $C$.pterostictum (Characidiinae) in a coastal stream of Atlantic Forest (Southern Brazil). Braz. Arch. Biol. Technol. 43: 527-531.

Barreto, A.P. \& J.M.R. Aranha. 2006. Alimentação de quatro espécies de Characiformes de um riacho da Floresta Atlântica, Guaraqueçaba, Paraná, Brasil. Rev. Bras. de Zool. 23: 779-788.

Bennemann, S.T., A.M. Gealh, M.L. Lorsi \& L.M. Souza. 2005. Ocorrência e ecologia trófica de quatro espécies de Astyanax (Characidae) em diferentes rios da bacia do rio Tibagi, Paraná, Brasil. Iheringia, Sér. Zool 95: 247-254.

Borror, D.J. \& D.M. Delong. 2005. Study of insects. Thomson Learning Academic Resource Center, Belmont, USA.

Carvalho, A.L., P.C. Werneck-de-Carvalho \& E.R. Calil. 2001. Description of the larvae of two species of Dasythemis karsch, with a key to the genera of Libellulidae occurring in the states of Rio de Janeiro and São Paulo, Brazil (Anisoptera). Odonatologica 31: 23-33.

Carvalho, A.L. 1992. Revalidation of the genus Remartinia Navás, 1911, with the description of a new species and a key to the genera of Neotropical Aeshnidae (Anisoptera). Odonatologica 21: 289-298.

Carvalho, A.L. 1989. Description of the larva of Neuraeschna costalis (Burmeister), with notes of its biology, and a key to the genera of Brazilian Aeshnidae Larvae (Anisoptera). Odonatologica 18: 325-332.

Carvalho, L.N. 2008. História Natural de peixes de igarapés amazônicos: utilizando a abordagem do Conceito do Rio Contínuo. Ph.D. Thesis, Instituto Nacional de Pesquisas da Amazônia, Manaus, Brazil.

Casatti, L., F. Langeani \& R.M.C. Castro. 2001. Peixes de riacho do Parque Estadual Morro do Diabo, bacia do Alto Rio Paraná, SP. Biota Neotropica 1: 1-15.

Cooper, S.D., S.J. Walde \& B.L. Peckarsky. 1990. Prey exchange-rates and the impact of predators on prey populations in streams. Ecology 71: 1503-1514. 
Cooper, S.D., D.W. Smith \& J.R. Bence. 1985. Prey selection by freshwater predators with different foraging strategies. Can. J. Fish. Aquat. Sci. 42: 1720-1732.

Costa, W.J.E.M. 1987. Feeding habits of a fish community in a Tropical Coastal Stream, Rio Mato Grosso, Brazil. Stud. Neo. Fau. Envir. 22: 145-153.

Deus, C.P. \& M. Petrere-Junior. 2003. Seasonal diet shifts on seven fish species in an Atlantic Rainforest stream in southeastern Brazil. Braz. J. Biol. 63: 579-588.

Dill, L.M. 1983. Adaptive flexibility in the foraging behavior of fishes. Can. J. Fish. Aquat. Sci. 40: 398-408.

Dunbrack, R.L. \& L.M. Dill. 1983. A model of size dependent surface feeding in a stream dwelling salmonid. Environ. Biol. Fish. 8: 203-216.

Emlen, J.M. 1966. Role of time and energy in food preference. Am. Nat. 100: 611-617.

Esteves, K.E. \& J. Lobón-Cerviá. 2001. Composition and trophic structure of a fish community of a clear water Atlantic rainforest stream in southeastern Brazil. Environ. Biol. Fish. 62: 429-440.

Flecker, A.S. 1992. Fish predation and the evolution of invertebrate drift periodicity - evidence from Neotropical streams. Ecology 73: 438-448.

Gatz Jr., A.J. 1979. Ecological morphology of freshwater stream fishes. Tulane Stud. Zool. Bot. 21: 91-124.

Gelwick, F.P., M.S. Stock \& W.J. Matthews. 1997. Effects of fish, water depth, and predation risk on patch dynamics in a north-temperate river ecosystem. Oikos 80: 382-398.

Gerking, S.D. 1994. Feeding ecology of fishes. Academic, San Diego, USA.

Gill, A.B. 2003. The dynamics of prey choice in fish: the importance of prey size and satiation. J. Fish. Biol. 63: $105-116$.

Gomiero, L.M. \& F.M.S. Braga. 2008. Feeding habits of the ichthyofauna in a protected area in the state of São Paulo, southeastern Brazil. Biota Neotrop. 8: 41-47.

Gregory, M.P.M., A.R. Davis \& D.J. Ayre. 2007. Diet and feeding periodicity of Cox's gudgeon Gobiomorphus coxii (Krefft) in a south-eastern Australian stream. J. Fish Biol. 71: 993-1006.
Hyslop, E.J. 1980. Stomach contents analysis - a review of methods and their application. J. Fish Biol. 17: 411-429.

Keenleyside, M.H.A. 1979. Zoophysiology, diversity and adaptation in fish behavior. Berlin, Springer-Verlag, Germany.

Krebs, C.J. 1989. Ecological methodology. Harper Collins, New York, USA.

Lechowicz, M.J. 1982. The sampling characteristics of electivity indexes. Oecologia 52: 22-30.

Lobón-Cervia, J. \& S. Bennemann. 2000. Temporal trophic shifts and feeding diversity in two sympatric, neotropical, omnivorous fishes: Astyanax bimaculatus and Pimelodus maculatus in Rio Tibagi (Paraná, Southern Brazil). Arch. Hydrobiol. 149: 285-306.

Lucinda, P.H.F. 2008 Systematics and biogeography of the genus Phalloceros Eigenmann, 1907 (Cyprinodontiformes: Poeciliidae: Poeciliinae), with the description of twenty-one new species. Neotrop. Ichthyol. 6: 113-158.

MacArthur, R.H. \& E.R. Pianka. 1966. On optimal use of a patchy environment. Am. Nat. 100: 603-609.

Manly, B.F.J., L.L. Mcdonald \& D.L. Thomas. 1993. Resource selection by animals: Statistical design and analysis for field studies. Chapman \& Hall, New York, USA.

Mazzoni, R., M. Moraes, C.F. Rezende, R. Iglesias-Rios. 2010. Diet and feeding daily rhythm of Pimelodella lateristriga (Osteichthyes, Siluriformes) in a coastal stream from Serra do Mar-RJ. Braz. J. Biol. 70: 1123-1129.

Mazzoni, R. \& L.D.S. da Costa. 2007. Feeding ecology of stream-dwelling fishes from a coastal stream in the southeast of Brazil. Braz. Arch. Biol. Technol. 50: 627-635.

Mazzoni, R., N. Fenerich-Verani \& E.P. Caramaschi. 2000. Electrofishing as a sampling technique for coastal stream fish populations and communities in the southeast of Brazil. Rev. Bras. Biol. 60: 205-216.

Merritt, R.W. \& K.W. Cummins. 1996. An introduction to the aquatic insects of North America. Kendall Hunt, Iowa, USA.

Mittelbach, G.G. 1981. Foraging efficiency and body size - a study of optimal diet and habitat use by Bluegills. Ecology 62: 1370-1386. 
Myers, N., R.A. Mittermeier, C.G. Mittermeier, G.A.B. Fonseca \& J. Kent. 2000. Biodiversity hotspots for conservation priorities. Nature 403: 853-858.

Novakowski, G.C., N.S. Hahn \& F. Rosemara. 2008. Diet seasonality and food overlap of the fish assemblage in a pantanal pond. Neotrop. Ichthyol. 6: 567-576.

Olifiers, M.H., L.F.M. Dorvillé \& J.L. Nessimian. 2004 . A key to Brazilian genera of Plecoptera (Insecta) based on nymphs. Zootaxa 651: 1-15.

Passos, M.I.S., J.L. Nessimian \& N.F. Junior. 2007. Chaves para identificação dos gêneros de Elmidae (Coleoptera) ocorrentes no estado do Rio de Janeiro, Brasil. Rev. Bras. Entomol. 51: 42-53.

Pes, A.M.O., N. Hamada \& J.L. Nessimian. 2005. Chaves de identificação de larvas para famílias e gêneros de Trichoptera (Insecta) da Amazônia Central, Brasil. Ver. Bras. Entomol. 49: 181-204.

Pinto, T.L.F. \& V.S. Uieda. 2007. Aquatic insects selected as food for fishes of a tropical stream: Are there spatial and seasonal differences in their selectivity? Acta Limnol. Bras. 19: 67-78.

Por, F.D. 1992. Sooretama, the Atlantic rain forest of Brazil. SPB Academic, The Hague, Netherlands.

Rezende, C.F., M. Moraes, L.M. Manna, R.P. Leitão, E.P. Caramaschi \& R. Mazzoni. 2010. Mesohabitat indicator species in a coastal stream of the Atlantic rainforest, Rio de Janeiro-Brazil. Rev. Biol. Trop. 58: 1479-1487.

Rezende, C.F. 2009. Ritmo alimentar, dieta e seleção de presas em três espécies de peixes de um riacho costeiro, Rio Mato Grosso-RJ. Ph.D. Thesis, Universidade Federal do Rio de Janeiro, Rio de Janeiro, Brazil.

Rezende, C.F. \& R. Mazzoni. 2006. Availability and use of allochthonous resources for Bryconamericus microcephalus (Miranda-Ribeiro) (Actinopterygii,
Characidae), at Andorinha Stream, Ilha grande, Rio de Janeiro, Brazil. Rev. Bras. Zool. 23: 218-222.

Rincón, P.A. \& J. Lobón-Cerviá. 1999. Prey-size selection by brown trout (Salmo trutta L.) in a stream in northern Spain. Can. J. Zool. 77: 755-765.

Ross, S.T. 1986. Resource partitioning in fish assemblages - a review of field studies. Copeia 2: 352-388.

Sabino, J. \& R.M.C. Castro. 1990. Alimentação, período de atividade e distribuição espacial dos peixes de um riacho da floresta Atlântica (Sudeste do Brasil). Rev. Bras. Biol. 50: 23-36.

Salles, F.F., E.R. Da-Silva, J.E. Serrão \& C.N. Francischetti. 2004. Baetidae (Ephemeroptera) na região Sudeste do Brasil: Novos registros e chave para os gêneros no estágio ninfal. Neotrop. Entomol. 33: 725-735.

Sazima, I. 1986. Similarities in feeding-behavior between some marine and fresh-water fishes in two tropical communities. J. Fish Biol. 29: 53-65.

Schoener, T.W. 1971. Theory of feeding strategies. Ann. Rev. Ecol. Systemat. 2: 369-404.

Sih, A. \& B. Christensen. 2001. Optimal diet theory: when does it work, and when and why does it fail? Anim. Behav. 61: 379-390.

Stephens, D.W. \& J.R. Krebs. 1986. Foraging theory. Princeton University, New Jersey, USA.

Warburton, K. 2003. Learning of foraging skills by fish. Fish Fish. 4: 203-215.

Werner, E.E. \& D.J. Hall. 1974. Optimal foraging and size selection of prey by Bluegill Sunfish (Lepomis macrochirus). Ecology 55: 1042-1052.

Wooster, D.E. 1998. Amphipod (Gammarus minus) responses to predators and predator impact on amphipod density. Oecologia 115: 253-259. 